\title{
11. Academic women and research leadership in twentieth-century Australia
}

\section{Patricia Grimshaw ${ }^{1}$ and Rosemary Francis ${ }^{2}$}

While the focus of analysis of leadership in tertiary institutions is most commonly the capacities of the most senior academic administrators, many academics at less elevated levels in the hierarchy also can exert major influence in their disciplinary areas that has significant impact nationally and internationally. This chapter offers an insight into Australian women's leadership in the academic profession in the twentieth century through the careers of outstanding scholars who from the mid 1950s were elected fellows of the Australian learned academies. Women faced considerable barriers to employment in universities before the expansion of secondary and tertiary education in the postwar years increased their opportunities to gain academic positions and advance the cutting edges of their disciplines. Yet, starting in 1956, when the first woman was elected to a learned academy, talented women were singled out as research leaders through this peer evaluation of their importance. With the social changes in gender expectations that the women's movement inspired and the Australian Labor Party's affirmative action policies of the 1980s, the number of female senior scholars who reached this standing increased markedly-noticeable especially in the humanities and social sciences. First, this chapter considers the careers of the first group of academicians who were elected to the four academies from 1956 to 1976; second, it traces the election of women from the late 1970s to the end of the century, including a few scholars who became leaders of the academies themselves. The story of academic women and research leadership is overall one of progressive change, but also indicates that gender equity has yet to be attained in the academic profession or, consequently, in the learned academies.

In an interview in 1997, the recently retired Professor Mollie Holman, a leading physiologist, who in 1970 had become the third woman elected a fellow of the Australian Academy of Science, recalled with warmth and gratitude her long and satisfying career. But she referred also to the challenges the academic profession presented to its members by the last decade of the twentieth century:

1 The University of Melbourne.

2 The University of Melbourne. 
Every academic has got three responsibilities, three jobs in one lifetime: one is to be an administrator, one is to be a teacher and one is to be a researcher. It's virtually impossible to be fully satisfied that you've done well in any of the three areas ... It's an impossible life being an

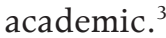

Recent scholarly studies of women's leadership in academia have focused primarily on those people who have filled the highest positions in academic administration. In Australian universities the appointment of female vicechancellors and deputy vice-chancellors has been a recent phenomenon and numbers remain relatively few. ${ }^{4}$ Yet as the political scientist Amanda Sinclair has suggested, if we view leadership as the exercise of influence, rather than associate it simply with those who fill top executive or administrative positions, we may discern how power resides in people at lower levels in hierarchical systems. ${ }^{5}$ This chapter focuses on women's leadership in research in the Australian academic profession, through the experiences of creative scholars elected by their scholarly peers as fellows of the learned academies. The pursuit of curiosity-based research is the distinguishing factor of the work expectations of academics; it is the core area on which entry to, and promotions within, the profession has crucially depended and on which universities themselves have been ranked against each other. Election to a learned academy has provided a marker of excellence in research that has not until very recently existed for teaching and administration. For those at the coalface of academic working life, teaching commitments have often overridden other demands. Yet teaching has been notoriously difficult to assess and remains so, despite such innovations as student questionnaires and staff prizes for outstanding performance. The

3 Mollie Holman, Interviewed by Ragbir Bhathal, 1997, National Library of Australia Oral History and Folklore Collection, ORAL TRC 3600, National Library of Australia, Canberra [hereinafter Holman Interview]; see also Ragbir Bhathal, 'Mollie Holman: Physiologist', in Profiles: Australian Women Scientists, ed. Ragbir Bhathal (Canberra: National Library of Australia, 1999), 99-106.

4 For a discussion, see: Tanya Fitzgerald, Julie White and Helen M. Gunter, eds, Hard Labour? Academic Work and the Changing Landscape of Higher Education (Bingley, UK: Emerald Electronic Resource, 2012); Colleen Chesterman, Anne Ross-Smith and Margaret Peters, 'Changing the Landscape? Women in Academic Leadership in Australia', http://65.54.113.26/Publication/6223987/changing-the-landscape-women-inacademic-leadership-in-australia, 11. See also: Colleen Chesterman, Anne Ross-Smith and Margaret Peters, "Not Doable Jobs": Exploring Women's Attitudes to Academic Leadership Roles', Women's Studies International Forum 28(2) (2005): 163-80; Colleen Chesterman, Anne Ross-Smith and Margaret Peters, 'The Gendered Impact on Organisations of a Critical Mass of Women in Senior Management', Policy and Society 24(4) (2005): 69-91.

5 Amanda Sinclair, 'Not Just “Adding Women In": Women Re-Making Leadership', in Seizing the Initiative: Australian Women Leaders in Politics, Workplaces and Communities, eds Rosemary Francis, Patricia Grimshaw and Ann Standish (Melbourne: eScholarship Research Centre, University of Melbourne, 2012), 5-36. See also: Amanda Sinclair, Leadership for the Disillusioned: Moving beyond Myths and Heroes to Leading that Liberates (Sydney: Allen \& Unwin, 2007); Amanda Sinclair, Doing Leadership Differently: Gender, Power, and Sexuality in a Changing Business Culture (Melbourne: Melbourne University Press, 1998). 
assessment of success in administration has been even more problematic, and again remains anecdotal despite the existence of appraisals and university 'climate surveys'.

Historically there were sharp challenges to talented women's aspirations to academic work embedded in the social structures that shaped women's access to tertiary degrees and advanced research opportunities. After women gained entry to universities and the granting of political citizenship, some women, emboldened by the first women's movement, slowly broke down barriers to entry to professions of high status and generous remuneration. Few women, however, entered the academic profession or rose far up its hierarchy before World War II. They had a more numerous presence following the postwar expansion of the tertiary sector when the second wave of the women's movement stimulated increasing acceptance of women, including married women, in the profession. By the end of the twentieth and the start of the twenty-first centuries, women's place in teaching, research and senior administration in the tertiary sector was secure, if unevenly spread-remarkable given the few decades in which this was achieved. ${ }^{6}$ This chapter explores this transition through the example of women's leadership in research. It considers the challenging gender culture of academia that shaped the careers of the first women academicians and their research profiles that led to their election to the learned academies from 1956 to 1976. It then considers the rapid increase in the ranks of female academicians that started in the late 1970s and continued to the end of the century, noting the wider opportunities of these academicians to develop more varied working histories.

The first women in the academies had been educated in tertiary institutions where they had very few female mentors, and had often been among the first women employed in lectureships in their disciplines. They were not usually helped by the nature of entry to the profession. As a form of employment, academic work has been anomalous within the history of other professions in which entry is controlled by formal credentials that may be monitored and revised, but remain foundational. Early in the twentieth century, during the formation of professions, aspirants might have gained entry through an apprenticeship or

6 For recent histories of Australian universities, see Julia Horne and Geoff Sherington, Sydney: The Making of a Public University (Melbourne: Melbourne University Publishing, 2012); Graeme Davison and Kate Murphy, University Unlimited: The Monash Story (Sydney: Allen \& Unwin, 2012); Stuart Macintyre and Richard Selleck, A Short History of the University of Melbourne (Melbourne: Melbourne University Press, 2003); John Poynter and Carolyn Rasmussen, A History of the University of Melbourne, 1935-1975 (Melbourne: J. R. Poynter, 1995); Patricia Grimshaw and Lynne Strachan, eds, The Half-Open Door: Sixteen Modern Australian Women Look at Professional Life and Achievement (Sydney: Hale \& Iremonger, 1982); Bettina Cass, Why So Few? Women Academics in Australian Universities (Sydney: University of Sydney Press, 1983); Madge Dawson and Heather Radi, eds, Against the Odds: Fifteen Professional Women Reflect on their Lives and Careers (Sydney: Hale \& Iremonger, 1984); Patricia Crawford and Myrna Tonkinson, The Missing Chapters: Women Staff at the University of Western Australia, 1963-1987 (Perth: Centre for Western Australian History, University of Western Australia, 1988). 
self-education. Gradually, however, the pathways to acceptance as a legitimate doctor, lawyer, engineer, accountant, architect, dentist, schoolteacher, social worker or nurse became subject to qualifications acquired through post-school training - usually accredited degrees from tertiary institutions. Although in the post World War II years a doctorate in process or completed and some record of scholarly publication became anticipated, academic employment sustained inexact criteria for entry and, once inside, for evaluation of performance. Selection committees might take into consideration alongside the candidate's achievement the standing of the supervisor and the university in which the doctorate was completed. Committees needed to rank the significance of a plethora of papers published in scholarly journals, chapters in scholarly collections and monographs, and the originality of completed research. Even more subjectively, they considered a candidate's potential for cutting-edge discovery across a working lifetime. ${ }^{7}$ Then again, there could be considerable discrepancy in how committees evaluated scholarly output against a record of successful performance in teaching. Members of selection panels, in addition, interviewed candidates and rated a scholar's capacity to fit well into a particular academic culture of students and colleagues, or to engage persuasively with various audiences. Conscious and unconscious bias against women could thrive in the fluid circumstances of academic appointments without attracting notice, let alone offering the bases for a female candidate to mount explicit challenges on the basis of gender. ${ }^{8}$

Australian universities were coeducational institutions substantially reliant on government; there was a thin affluent middle class in Australia, and what little wealth was devoted to philanthropy was not commonly funnelled to universities. That was left to governments to do, as was much else. With a numerically much reduced Indigenous people and settler governments hostile to the migration of their Asian neighbours, the country sustained a relatively small and socially provincial population. Given the reliance on primary production and practical, anti-intellectual attitudes, aspirants for tertiary degrees were few. Women students clustered mainly in the humanities or sciences, not usually prepared for, or consciously avoiding, the professional faculties like medicine and law that in any case openly discouraged women.

7 See Michele Lamont, How Professors Think: Inside the Curious World of Academic Judgment (Cambridge, Mass.: Harvard University Press, 2009); Pierre Bourdieu, Homo Academicus (Paris: Editions de Minuit, 1984); Raewyn Connell and June Crawford, 'Mapping the Intellectual Labour Process', Journal of Sociology 43(2) (2007): 187-205; Raewyn Connell, 'Core Activity: Reflexive Intellectual Workers and Cultural Crisis', Journal of Sociology 42(1) (2006): 5-23; Paul Boreham, Alec Pemberton and Paul Wilson, eds, The Professions in Australia: A Critical Appraisal (Brisbane: University of Queensland Press, 1976).

8 Margaret Thornton, "The Mirage of Merit: Constructing the "Ideal Academic"', Paper presented at the Symposium on Workplace Culture in Higher Education, University of Melbourne, October 2011. See also Anne Witz, Professions and Patriarchy (London and New York: Routledge, 1992). 
Engagement with sustained research usually relied on academic employment and up to the 1970s women were seldom found in tenured lectureships. The extension of social and political rights to women by 1902 had not counteracted impediments to women's entry to professional employment outside nursing and teaching. ${ }^{9}$ Employment in the professions that commanded high status and salaries was strongly embedded in class and gender divisions. Only a select number of women had access to academically oriented secondary educations in fee-paying schools and to expensive university degrees. A woman needed not only to harbour enthusiasm for extended years of education but also to have parents who were prepared to fund them. Moreover, although Australia had a reputation for egalitarianism, a strong gender division of labour blocked most educated married women's access to wage earning; only adult unmarried daughters might be permitted to pursue careers. ${ }^{10}$ Marriage bars in place in a number of workplaces obliged women to give up tenured positions on marriage, and in addition social pressure sufficed to dissuade married women from waged work if they had children.

The few women academics appointed to lectureships from the 1900s up to the 1960s needed to survive burdensome workloads in understaffed departments where lecturers had to assume most tasks necessary to protect the credentialling process for student degrees. The universities before the expansion of the postwar period were small institutions where male professors, with a small entourage of staff, undertook the teaching and most administration. The gendered culture of academia and the conscious or unconscious discrimination of the academic culture were leavened by the outstanding liberalism of the few men who encouraged women's research endeavours. Let us look at the example at the University of Melbourne of the botanist Dr Ethel McLennan, who felt she had overestimated her capacities when she applied unsuccessfully in the late 1930s for the advertised professorship. The professor of bacteriology advised the selection committee:

Of her claims as a Scientist and Research worker there is no doubt. As to her ability to administer the Department and to re-organise it, I feel completely assured ... I believe that if this University is ever to appoint

\footnotetext{
9 Beverley Kingston, My Wife, My Daughter, and Poor Mary Ann: Women and Work in Australia (Melbourne: Thomas Nelson, 1975); Patricia Grimshaw, John Murphy and Belinda Probert, eds, Double Shift: Working Mothers and Social Change in Australia (Melbourne: Circa, 2005).

10 Janet McCalman, Journeyings: The Biography of a Middle-Class Generation 1920-1990 (Melbourne: Melbourne University Press, 1995); Alison Mackinnon, The New Women: Adelaide's Early Women Graduates (Adelaide: Wakefield Press, 1986); Alison Mackinnon, Love and Freedom: Professional Women and the Reshaping of Personal Life (Melbourne: Cambridge University Press, 1997); Alison Mackinnon, Women, Love and Learning: The Double Bind (New York: P. Lang, 2012).
} 
a woman to a Professorial Chair this opportunity should not be missed as we might go a very long time without ever again having so generally capable and fitting a person. ${ }^{11}$

She was passed over nevertheless for a young Englishman of promise. Her publication list would have been further developed, McLennan confessed, had she not had full responsibilities for junior classes three years in a row, because of the recurrent illnesses of the professor and the absence overseas of another colleague. 'Some of my friends encouraged me more than I was inclined to encourage myself', she explained apologetically. ${ }^{12}$

Even as late as the 1950s evidence of gender bias was not hard to find. In 1957 the eminent Sir Keith Hancock, head of the Research School of Social Sciences at The Australian National University, wrote to the vice-chancellor in jocular style offering his estimate of the value of appointing academic women: 'It is no private fad of my own to insist that good professors will not long continue to do their best work unless they are reinforced by charwomen..' ${ }^{13}$ And the archives of the University of Melbourne reveal another professor's attitudes that must have deflected all but the hardiest women from academic aspirations. In 1955 Professor John La Nauze was appointed to the second chair of the history school, a position many had expected would go to an associate professor, Kathleen Fitzpatrick, who finally did not apply. Following his appointment, he wrote to assure Fitzpatrick of her continuing value to the school, to the other professor, Max Crawford, and not least to himself:

Well, instead of being left to your knitting, you will now have a double burden of keeping two men sane and charitable and calm. I have never imagined that it would be anything but a partnership of three, in which if two are active in the eyes of the world, the third will often bear burdens but not get applause. I think it will be a pretty sound firm. ${ }^{14}$

Despite such disparagement, Fitzpatrick was in fact to become an inaugural member of the Australian Academy of the Humanities (AAH): her achievements figure below.

\footnotetext{
11 'Prof. Woodruff to the Vice Chancellor', 14 December 1937, McLennan Papers, cited in Jane Carey, 'Departing from their Sphere? Australian Women and Science, 1880-1960' (PhD thesis, University of Melbourne, 2003), 240.

12 Cited in Farley Kelly, Degrees of Liberation: A Short History of Women in the University of Melbourne (Melbourne: Women Graduates Centenary Committee, University of Melbourne, 1985). For a fuller discussion, see: Patricia Grimshaw and Jane Carey, 'Foremothers VI: Kathleen Fitzpatrick (1905-1990), Margaret Kiddle (1914-1958) and Australian History after the Second World War', Gender \& History 13(2) (August 2001): 349-73.

13 Cited in 'ANU Presentation to the Review of the Institute of Advanced Studies 1990', Typescript, 73. We owe this reference to Charles Coppel.

14 'John La Nauze to Kathleen Fitzpatrick', 25 May 1955, in Kathleen Fitzpatrick Collection, Box 1, University of Melbourne Archives, Melbourne [hereinafter Fitzpatrick Collection].
} 
An advanced student and tutor in the history school and later an outstanding historian, Inga Clendinnen gave her opinions in a forum discussing this period: 'We were meant to go on and be the carers, the primary carers, as it were, of the tutorial classes, but as for being groomed for greatness, no.' Professor La Nauze had assured Clendinnen she was the most intelligent student he had ever taught, but he would never recommend her for a scholarship because she 'would simply marry and have babies. He would not recommend a woman for a scholarship'; nor, indeed, would he supervise a woman postgraduate. ${ }^{15}$ When a part-time lecturer, June Philipp, a married woman, asked for some time off when she was pregnant, a woman colleague reported:

As for La Nauze, the things he's saying about part-time lecturers, married female[s], potentialities of, are quite shocking and bode ill for the continuation of the species. He's torn between sadistic delight that June is being forced to fulfil her proper function and despair at the thought of coping with Australian History. ${ }^{16}$

This did not seem hopeful territory for the nurturance of female academicians.

Three of the country's learned academies emerged from committees of leading academics who were involved during World War II and the immediate postwar years in planning for postwar reconstruction. ${ }^{17}$ The Australian Academy of Science (AAS) was founded in 1954 by Australian fellows of the Royal Society of London, with Sir Mark Oliphant as its founding president. ${ }^{18}$ Prominent academics in the humanities and social sciences set up separate councils, the Humanities Research Council and the Social Sciences Research Council, which converted into the two learned academies: the Australian Academy of the Humanities (AAH), established in 1969, ${ }^{19}$ and the Academy of the Social Sciences in Australia (ASSA), which formed in 1971. The fourth learned academy was the Australian Academy of Technological Sciences (ATS), established in 1976 when applied scientists felt the need for a distinct academy separate from the AAS; ${ }^{20}$ the ATS eventually incorporated engineers and used the acronym ATSE. The means by which fellows were elected differed slightly between the academies, but basic to it was the promotion of a candidate by several fellows, an initial assessment from the appropriate disciplinary section through a secret ballot

15 'Second Discussion Session', in Stuart Macintyre and Peter McPhee eds, Max Crawford's School of History (Melbourne: History Department, University of Melbourne, 2000), 75.

16 'Margaret Kiddle to Max Crawford', 29 January 1958, Fitzpatrick Collection, Box 16.

17 See Stuart Macintyre, The Poor Relation: A History of the Social Sciences in Australia (Melbourne: Melbourne University Press, 2010).

18 See Frank Fenner, The Australian Academy of Science: The First Twenty-Five Years (Canberra: Australian Academy of Science, 1980).

19 Graeme Davison wrote on the inauguration of the AAH in 'Phoenix Rising: The Academy and the Humanities in 1969', Humanities Australia 1 (2010): 6-14.

20 See John W. Zillman, ATSE 1975-2005: The First 30 Years - A Short History of the Origins and Development of the Australian Academy of Technological Sciences and Engineering (ATSE) (Melbourne: ATSE, 2005). 
and, if there was sufficient approval, the confirmation of a candidate through a vote of the entire membership. The AAS had a tight restriction on the number of new fellows elected from each section. While the AAH and the ASSA similarly grouped fellows into disciplinary interest groups, they were more flexible in their evaluations of scholarly achievement. There have of course been numerous excellent scholars who have escaped identification as potential academicians: indeed, some used to assert that one's chances of being nominated for an academy lessened with every mile of distance from Canberra. We can nevertheless say that those who were elected to fellowships were outstanding in research.

Despite an unwelcoming academic climate in the universities in the early decades of the century, some senior male academics stood out for their keenness to nurture the academic aspirations of women, some of whom received institutional support for excellent careers. Fifteen women became fellows of the learned academies between 1956, when the first woman, Dorothy Hill, was elected to the AAS, and 1976, when two women became inaugural fellows of the ATS. Five of the fellows were pure or applied scientists, and 10 were from the humanities and social sciences. Seven of the 15 fellows were born before or during World War I, and the remaining eight were born in the 1920s and 1930s. Three were born outside Australia and almost all, if they undertook doctorates, did so in overseas universities; just one graduated a PhD from an Australian university, but this followed advanced research experience in two northern countries. All travelled on diverse pathways to research prominence, sustained by their families' investment in their educational achievements and by the encouragement of (usually) male university mentors. Their ultimate success, however, was a tribute to their personal talents, ingenuity and determination. ${ }^{21}$ Their careers constituted notable achievement in an academic climate generally discouraging of female endeavour. Their leadership lay not only in their innovation in their disciplines but also in their pioneering status, which gave heart and encouragement to other women who followed them. Many of these pioneers, of course, mentored a rising generation of young women scholars.

The fellows elected to the AAS entered tertiary institutions straight from school, proceeded into doctoral studies without a lengthy break and entered tertiary employment with exemplary track records. They were prominent in geology, mathematics and physiology. The first academician, Queensland geologist Dorothy Hill, was elected to the AAS in 1956 at the age of forty-nine. Born in Brisbane in 1907, she undertook a science degree at the University of Queensland, where she graduated in 1928 with first-class honours in geology. She

\footnotetext{
21 For a fuller examination of the careers of the first female academicians, see: Patricia Grimshaw and Rosemary Francis, 'Women Research Leaders in the Australian Learned Academies: 1954-1976', in Seizing the Initiative: Australian Women Leaders in Politics, Workplaces and Communities, eds Rosemary Francis, Patricia Grimshaw and Ann Standish (Melbourne: eScholarship Research Centre, University of Melbourne, 2012), 223-46.
} 
then proceeded on a scholarship to Cambridge University, where she completed a doctorate focused on the study of corals that would become her continuing research area. Following short-term fellowships, Hill returned in 1937 to a position at her home university in Brisbane. Despite a career interrupted by years of war work, her publications when she became a fellow reflected a fine research engagement. ${ }^{22}$ Among other many later accomplishments, in 1970 Hill held a year's interim position as president of the AAS; it would be 25 years before another woman headed a learned academy.

There was a gap until 1969 when the academy elected the fifty-five-yearold mathematician Hanna Neumann. Like other academics in Australian universities, her education had been entirely gained abroad - in her case, her school education also, during a disturbed period. Born in Berlin in 1914, she graduated from the University of Berlin with distinction in 1936 and began postgraduate research at the University of Gottingen. In 1938 she joined her fiancé, the Jewish refugee and mathematician Bernhard Neumann, who had fled to England. There the couple married; they had five children. While her husband found temporary employment elsewhere, Hanna enrolled as an external student at Oxford University, pursuing doctoral research while living in a caravan with her growing family around her. ${ }^{23}$ She graduated DPhil in 1944 and was awarded an Oxford DSc in 1955. After holding academic positions in Britain, in 1962 she was appointed, along with her husband, to The Australian National University, where she was eventually promoted to a professorship. A specialist in group theory and a mathematician of profound originality, she died of a brain aneurism in 1971, two years after her election.

The physiologist Mollie Holman was aged forty when in 1970 she became the third woman elected to the AAS. Born in Launceston in 1930, the daughter of a radiologist, her secondary education was completed at Merton Hall in Melbourne. She proceeded to an undergraduate degree at the University of Melbourne with a BSc in 1952 and an MA in physiology under Professor Douglas Wright in 1955. For her doctorate at Oxford University, she focused

22 'Dr John Cole, Interview with Dorothy Hill', 1981, www.science.org.au/fellows/memoirs.hill.html; K. S. W Campbell and J. S. Jell, 'Dorothy Hill 1907-1997', Historical Records of Australian Science 12(2) (1998): 205-28; Tim Sherratt, 'Finding Life in Ancient Corals: Dorothy Hill', Australasian Science (Summer 1995), Australian Science Archives Project, www.asap.unimelb.edu.au/bsparcs/exhib/journal/as. See also: http://www.australianwomen.info. For Australian women in science, see: Carey, 'Departing from their Sphere?'; Claire Hooker, Irresistible Forces: Australian Women in Science (Melbourne: Melbourne University Press, 2004); Ragbir Bhathal, ed., Profiles: Australian Women Scientists (Canberra: National Library of Australia, 1999).

23 Kenneth F. Fowler, 'Neumann, Hanna (1914-1971)', in Australian Dictionary of Biography. Volume 15 (Melbourne: Melbourne University Press, 2000), 465; Michael Newman and Gordon Wall, 'Hanna Neumann 1914-1971', Records of the Australian Academy of Science 3(2) (1975), www.science.org.au/fellows/memoirs. hill.html; G. E. Wall, 'Hanna Neumann', Journal of the Australian Mathematical Society 17(1) (1974): 1-28; Rosanne Walker, 'Hanna Neumann (1914-1971)', Australasian Science 22(1) (2001): 46; 'Interview by Professor Bob Crompton with Bernard Neumann', 1998, www.science.org.au/scientists/interviews/html. 
on the interaction of nerve cells with smooth muscles in the body, which she would continue to develop into what became major research findings. When she returned to a lectureship at the University of Melbourne, she found she had been allocated a laboratory in the university paint shop. She moved quite soon in 1963 to a senior lectureship at Monash University, where in 1970 she received a personal chair, and where she stayed throughout her career. ${ }^{24}$

The AAH appointed four women as inaugural fellows in 1969: two historians, an art historian and a specialist in literary studies. Three were serving members of the Humanities Research Council: Ursula Hoff, Marnie Bassett and Kathleen Fitzpatrick. Ursula Hoff, sixty years of age in 1969, had experienced-as was the case with Neumann - an education disrupted by the rise of Nazism. Born in London in 1909 to German Jewish parents, she graduated from Hamburg University in English literature and art history, but fled with her family to London in 1933 when Hitler came to power. She returned to Hamburg to complete her doctoral thesis on Rembrandt in 1935. She found work in prestigious London museums before migrating to Australia in 1939 to take up a secretarial position at University Women's College in Melbourne. Eventually she worked as keeper of prints and drawings in the National Gallery of Victoria and as lecturer in art history at the University of Melbourne. She was widely esteemed for her significant studies of European and Australian art history and enjoyed a very long and distinguished career until her death in Melbourne in 2005. ${ }^{25}$

The historians Kathleen Fitzpatrick and Marnie Bassett and the literary critic and poet Judith Wright did not hold doctorates: it was their highly respected published writing that had established their scholarly reputations. ${ }^{26}$ Fitzpatrick, mentioned above for a new professor's condescending treatment, was sixty-four when she became a foundation member of the AAH, seven years after retiring from the history school at the University of Melbourne. ${ }^{27}$ She was born in rural Victoria in 1905, completed a BA honours at the University of Melbourne in 1926 and two years later a second BA, at Oxford University. She returned to

24 Holman Interview; Bhathal, Profiles, 99-106; 'Interview by Dr Max Blythe', 1998, www.science.org.au/ scientists/interviews/html; Bhathal, 'Mollie Holman'. For other studies of women in science, see: Farley Kelly, On the Edge of Discovery: Australian Women in Science (Melbourne: Text Publishing, 1993).

25 Jaynie Anderson, 'Ursula Hoff (1909-2005)', http://www.humanities.org.au/Fellowship/Obituaries.aspx; Colin Holden, The Outsider: A Portrait of Ursula Hoff (Melbourne: Australian Scholarly Publishing, 2009).

26 Kathleen Fitzpatrick, Solid Bluestone Foundations and Other Memories of a Melbourne Girlhood 19081928 (Melbourne: Macmillan, 1983); Kathleen Fitzpatrick, 'A Cloistered Life', in The Half-Open Door: Sixteen Modern Australian Women Look at Professional Life and Achievement, eds Patricia Grimshaw and Lynne Strahan (Sydney: Hale \& Iremonger, 1982), 118-33.

27 Alison Patrick, 'Fitzpatrick, Kathleen Elizabeth (1905-1990)', Australian Dictionary of Biography Online (Canberra: National Centre of Biography, The Australian National University), http://adb.anu.edu. au/biography/fitzpatrick/kathleen-elizabeth-12500/text22491; Jane Carey and Patricia Grimshaw, Women Historians and Women's History: Kathleen Fitzpatrick (1905-1990), Margaret Kiddle (1914-1958) and the Melbourne History School (Melbourne: Department of History, University of Melbourne, 2001); Kathleen Fitzpatrick, Martin Boyd (Melbourne: Lansdowne Press, 1963). 
Australia to a temporary lecturing appointment but on her marriage to Brian Fitzpatrick in 1932, as was required of married women, she had to resign. Following a divorce, she returned to a lectureship in the history school at Melbourne in 1939. She served in the war as president of the Council for Women in War Work, and was promoted in the school to senior lecturer in 1942 and associate professor in 1948. She acted as head of department in the professor's absences and became celebrated as a gifted teacher. By the time of her admission to the AAH in 1969, Fitzpatrick's publications included biographies of Sir John Franklin and Martin Boyd and a study of Australian explorers. ${ }^{28}$ She proceeded to research and publish, including an acclaimed autobiography, Solid Bluestone Foundations, until her death in 1990.

The most senior of the first group of academicians, Marnie Bassett, was eighty at her admission to the AAH. Born in Melbourne in 1889 and educated at home by governesses, she was refused permission by her mother to enrol in a degree and instead she worked as a secretary for her academic father. A lover of history, she audited lectures at the University of Melbourne, where Professor Ernest Scott fostered her early research. After war work, she married and postponed ambitions to undertake research as she raised her three children. From 1940, however, she published a steady stream of books that swiftly became classics of Australian history; particularly impressive was her biographical writing on colonial subjects, The Governor's Lady (1940) and The Hentys: A Colonial Tapestry (1954). Monash University awarded her an honorary DLitt degree in 1968; the University of Melbourne did likewise in $1974 .{ }^{29}$ She died in 1980. The fourth of the inaugural fellows was the poet Judith Wright McKinney, better known as Judith Wright. She was born on a pastoral station in northern New South Wales in 1915, was educated at home and attended boarding school for her final secondary years. She began a BA degree at the University of Sydney but could not graduate because she had not matriculated, lacking the required standard in mathematics. Nevertheless, for a period Wright tutored casually in the English Department at the University of Sydney. ${ }^{30}$ By 1969, when she was elected to the $\mathrm{AAH}$, her critical literary writing was widely admired, but even more so, her poetry. Her output and reputation continued to grow up to her death in 2000.

The remaining two AAH fellows appointed up to 1976 were the scholar of English Leonie Kramer and the French literary specialist Judith Robinson-Valery. Both

\footnotetext{
28 See Grimshaw and Carey, 'Foremothers VI'.

29 Ann Blainey, 'Bassett, Lady Flora Marjorie (Marnie) (1889-1980)', Australian Dictionary of Biography Online (Canberra: National Centre of Biography, The Australian National University), http://adb.anu.edu.au/ biography/bassett-lady-flora-marjorie-marnie-9448/text16613.

30 Elizabeth Webby, 'Judith Wright McKinney (1915-2000) Obituary', http://www.humanities.org.au/ Fellowship/Obituaries.aspx; Judith Wright, Half a Lifetime, ed. Patricia Clarke (Melbourne: Text Publishing, 1999); Veronica Brady, South of My Days: A Biography of Judith Wright (Sydney: Angus \& Robertson, 1998).
} 
were Australian-born and educated and had undertaken postgraduate work abroad. The Canberra-born (in 1933) French language expert Judith RobinsonValery completed her doctorate at the Sorbonne in Paris following her first degree at the University of Sydney. Her thesis was published in 1958, while she held a research fellowship at Girton College, Cambridge. For 11 years from 1963, she held a professorship at the University of New South Wales, and was elected to the AAH in 1972 at the age of thirty-nine, cited as a distinguished scholar in French literature. She returned to Paris to live and work in 1974, and died there in 2010. ${ }^{31}$ Kramer, a specialist in Australian literature, was elected to the AAH in 1974. She was born Leonie Gibson in Melbourne in 1924 and was educated at the Presbyterian Ladies' College. After her undergraduate degree at the University of Melbourne, she completed a PhD at Oxford University, and returned to Australia to take up a lectureship at the University of New South Wales. She became a professor at the University of Sydney in 1968 where she continued to pursue a productive and influential career that included a period as chancellor of the university. ${ }^{32}$

Unlike the situation in the AAH, there were no female members of the Social Science Research Council when most of the existing members became inaugural fellows of the ASSA in 1971: the outstanding English-born and Cambridgeeducated Pacific anthropologist Camilla Wedgwood, who had held a number of posts in Australia, had been a member but died in $1955 .{ }^{33}$ Norma McArthur, the notable demographer of the Pacific Islands, was elected as an inaugural fellow. She had moved from her Australian undergraduate degree to undertake research for a $\mathrm{PhD}$ at the University of London. No explanation is given for her decision to resign at the end of her first year in the ASSA. Her extensive original, path-breaking research continued to be consulted up to her death in 1984 and beyond. ${ }^{34}$

Several others of the early academicians in the ASSA undertook their doctoral research in the United States rather than the United Kingdom - a choice that, given American prominence in the fast-developing area, would grow in popularity. The sociologist Jean Martin was elected to the ASSA in its first year. Born in Melbourne in 1923, she completed an undergraduate degree at

\footnotetext{
31 Robert Pickering, 'Judith Robinson-Valery 1933-2012', Australian Journal of French Studies (September 2010); James Lawler, 'Robinson-Valery, Judith Ogilvie (1933-2010)', www.humanities.org.au/Fellowship/ Obituaries.aspx.

32 'Kramer, Leonie Judith', in The Oxford Companion to Australian History, eds Graeme Davison, John Hirst and Stuart Macintyre (Melbourne: Oxford University Press, 2000); 'Kramer, Leonie Judith, (1924-)', http:// www.womenaustralia.info/biogs/IMP0037b.htm.

33 David Wetherell, 'Wedgwood, Camilla Hildegarde (1901-1955)', Australian Dictionary of Biography Online (Canberra: National Centre of Biography, The Australian National University), http://adb.anu.edu.au/ biography/wedgwood-camilla-hildegarde-11992/text21503.

34 See 'McArthur, Norma (1921-1984)', Obituaries Australia Online (Canberra: National Centre of Biography, The Australian National University), http://oa.anu.edu.au/obituary/mcarthur-norma-677/text678.
} 
the University of Sydney before pursuing research at the London School of Economics and the University of Chicago. She returned to Australia and completed her PhD at The Australian National University. In 1965 she became the inaugural professor of sociology at La Trobe University. ${ }^{35}$ She died in 1979, having made a remarkable impact on the development of studies of migration and multicultural Australia. Two further early fellows were the legal scholar Enid Campbell and the sociologist Jacqueline Goodnow. Elected in 1972 at forty years of age, Campbell undertook a PhD at Duke University in North Carolina before taking up an appointment at Monash University; in 1967 she was promoted to a professorship. ${ }^{36}$ Campbell, renowned then and now as a gifted scholar of constitutional studies, died in 2012. Goodnow was elected to the ASSA in 1976. Born in Toowoomba, Queensland, she undertook her first degree at the University of Sydney, followed by a PhD from Harvard University; she was appointed a professor at Macquarie University in the year of her election. ${ }^{37}$ She was and remains highly influential in her field of the sociology of families, communities and cultures.

Finally, in the ranks of this group of early fellows were two women who figured among the inaugural fellows of the ATS(E) in 1976. Both were employed for most of their working lives in research institutes rather than in universities. The food scientist June Olley was born in London in 1924. She completed a $\mathrm{PhD}$ at the University of London and held a research position in Scotland before moving in 1968 to work in the Commonwealth Scientific and Industrial Research Organisation (CSIRO) in Tasmania. Olley was fifty-two years old when she became a fellow in the ATS in 1976 for her notable work as a fish technologist. The animal geneticist Helen Newton Turner was sixty-eight and retired when she was elected to the ATS in 1976. She was by then an internationally recognised world expert on sheep genetics, with research that had a substantial impact on merino sheep breeding. ${ }^{38}$ Born in Sydney in 1908, she graduated with a degree

35 Katy Richmond, 'Martin, Jean Isobel (1923-1979)', Australian Dictionary of Biography. Volume 15 (Melbourne: Melbourne University Press, 2000); Wilfred David Borrie, 'Dr Jean Isobel Martin', in Annual Report of the ASSA 1978-1979, 10. See also Macintyre, The Poor Relation.

36 Matthew Groves (ed.), Law and Government in Australia: Essays in Honour of Enid Campbell (Melbourne: Federation Press, 2005); Matthew Groves, 'Obituary: Enid Mona Campbell AC, OBE, 1932-2010', AIAL Forum 63 (2009): 1-3.

37 Academy of Social Sciences in Australia, 'Emeritus Professor Jacqueline Goodnow', Academy Fellows, http://www.assa.edu.au/fellowship/fellow/116; Jacqueline Goodnow, Interviewed by Nikki Henningham, 2005, National Library of Australia Oral History and Folklore Collection, NLA ORAL TRC 5547, National Library of Australia, Canberra; 'Jacqueline Jarrett Goodnow', in Women in Psychology: A Biobibliographic Sourcebook, eds A. N. O'Connell and M. K. Russo (New York: Greenwood Press, 1990), 134-42.

38 Helen Newton Turner, Interviewed by Ann Moyal, 1993, National Library of Australia Oral History and Folklore Collection, NLA ORAL TRC 2902, National Library of Australia, Canberra; Ann Moyal, ed., Portraits in Science (Canberra: National Library of Australia, 1994); Nessy Allen, 'Australian Women in Science: Two Unorthodox Careers', Women's Studies International Forum 15(5-6) (1992): 551-62; and Nessy Allen, 'Helen Newton Turner and the Wool Industry', Journal of Australian Studies 33 (1992): 56-62; Gavan McCarthy, 'Turner, Helen Alma Newton (1908-1995)', in Encyclopedia of Australian Science, www.eoas.info/biogs/ P004129b. 
in architecture from the University of Sydney, but, unemployed in the 1930s depression, she learned typing and found a job as a secretary to Dr Ian Clunies Ross in the Council for Scientific and Industrial Research (CSIR, later the CSIRO) division of animal health. Curious about the data she typed, she returned to university part-time to undertake statistics subjects. Impressed by her talent, Clunies Ross awarded her overseas leave to work alongside a foremost British statistician. She returned home to the post of senior research scientist in the Division of Animal Genetics, leading the team working on sheep genetics from 1956 to 1973. In 1970 she was awarded the degree of Doctor of Science at the University of Sydney. In retirement, she continued offering practical assistance in science nationally and internationally until her death in 1995.

Of this first group of academicians, Leonie Kramer, Judith Robinson-Valery, Jean Martin and Jacqueline Goodnow embarked on their first jobs as married women with children, and achieved their notable work under complex domestic and work conditions. It was an intimation of things to come, as marriage bars disappeared and new notions of the gender division of labour altered women's perceptions of balancing the work of care with waged work..$^{39}$ A postwar economic boom on the back of industrial development and a vigorous immigration policy brought marked changes in the capacity of the Australian workforce to include adult women as workers. Educational opportunities for girls at secondary level expanded along with the establishment of numerous new tertiary institutions. The number of women students in higher education grew and these students diversified their choices of courses to include the professional sector-for example, law and medicine. Significantly for the academic profession, the proportion also rose of women opting for research higher degrees, including the $\mathrm{PhD}$, which was emerging as essential for securing an ongoing lectureship. Not only did more women gain entry-point positions but also through promotion processes women began to hold positions at the upper levels of the academic ladder, including professorships, in increasing numbers. ${ }^{40}$

Beginning in the mid to late 1960s, there was an influx of married women into the waged workforce, including the academic profession, which increased the pool of talent very considerably. A major social movement, based in the labour movement and the separate middle-class women's groups, stimulated changes in attitudes towards women and women's own aspirations. ${ }^{41}$ These groups collaborated to undermine the entrenched notion of the family wage that had prioritised male waged work and to unsettle gender divisions within

39 Grimshaw et al., Double Shift.

40 Beverley Ward, 'The Female Professor: A Rare Australian Species, the Who and How' (PhD thesis, Murdoch University, Perth, 2003).

41 Marilyn Lake, Getting Equal: The History of Australian Feminism (Sydney: Allen \& Unwin, 1999). 
workplaces. ${ }^{42}$ The pace of women's entry into tertiary research quickened considerably with equal opportunity legislation and increasingly included women with children. The movement of aspirant female academics into advanced education, first employment and promotion benefited in the 1980s from the equal employment opportunity legislation seen through Federal Parliament by the Australian Labor Party government under Bob Hawke. The Sex Discrimination Act of 1984 outlawed discrimination on the basis of sex in employment and the Affirmative Action Act of 1986 made the reporting of statistics on women in the profession mandatory. Universities immediately established units to monitor women's employment and establish targets (not quotas) for the recruitment and promotion of women to the higher levels of the academic hierarchy. These innovations had a remarkable impact on the work situations of women in most tertiary institutions.

The pool of potential female researchers and hence of future academicians enlarged in an impressive fashion. The flow of women into the academies followed accordingly in the 1980s, 1990s and early 2000s. In 1976 the total membership of the AAS after 22 years of operation stood at 194, two of whom were women. In the same year there were 112 fellows of the AAH, five of whom were women, and 150 ASSA fellows - a number that included three women. The total membership of the ATS in its first year of 1976 was 64, including two women. With the increased number of women in a wider range of research degrees, their appearance at the upper levels of the academic ladder became commonplace. Far more potential fellows emerged and the critical mass of female fellows within the academies stimulated further nominations of women. Elections of women, especially in the AAH and the ASSA, edged up in the 1980s and then increased quite rapidly in the 1990s and 2000s.

The rate of increase was most marked in the ASSA. Following on from McArthur, Martin, Campbell and Goodnow in the early 1970s, it elected the anthropologist Marie Reay in 1977 and the geographer Fay Gale in 1979. In the 1980s nine further women were elected: political scientist Carole Pateman, historian Pat Jalland, economist Helen Hughes, Beverley Raphael in social medicine, lawyers Marcia Neave and Alice Tay, and three sociologists, Eva Etzioni-Halevy, Bettina Cass and Jane Marceau. In the 1990s it elected 46 women and in the 2000s, 72; and 10 more women were admitted as fellows in $2011 .^{43}$

There was also a noticeable increase in the elections of women to the AAH. Following Leonie Kramer in 1974, it elected the linguist Luise Hercus in 1978

\footnotetext{
42 Patricia Grimshaw, Nell Musgrove and Shurlee Swain, ‘The Australian Labour Movement and Working Mothers in the United Nation's Decade for Women, 1975-1985', in The Time of their Lives: The Eight Hour Day and Working Life, eds J. Kimber and P. Love (Melbourne: Australian Society for the Study of Labour History, 2007), 137-52.

43 See information on the ASSA website: www.assa.edu.au.
} 
and archaeologist Isabel McBride in 1979. The 1980s saw the election of nine women: in the arts and art history, Virginia Spate, Margaret Manion, Ann Galbally and Margaret Plant; in history, Dale Kent; in Asian studies, Margaret Kartomi; in archaeology, Sylvia Hallam and Betty Meehan; and Anna Wierzbicka in linguistics. In the 1990s, 30 women were elected and in the 2000s, a further $50 .{ }^{44}$

The increase was also apparent in the two science academies, although the record was less impressive. There were comparatively fewer women in professorial or other senior research posts in science but the science academies also appeared to resist any special efforts to identify and elect women of talent. ${ }^{45}$ No further women were elected to the AAS in the 1970s after Holman and in the 1980s just three more were admitted: palaeontologist Elizabeth Truswell, molecular geneticist Suzanne Cory and biologist Jan Anderson. These entry numbers tripled in the 1990s, with nine women elected, and in the first decade of the 2000s a further 20 women were elected. Turning to the ATSE, after its initial appointments in the inaugural year, the academy elected microbiologist Nancy Millis in 1977, followed in the 1980s by plant biologists Elizabeth Dennis and Adrienne Clarke. Seventeen more women were elected in the 1990s. By the end of 2012, just more than one-tenth of the AAS membership and just less than one-tenth of the ATSE were women. In comparison, about one-fifth of the fellows in the AAH and one-quarter in the ASSA were women. ${ }^{46}$

Among the outstanding women elected to the academies in these later years were five who became leaders of the academies themselves when they were elected president. The University of Sydney archaeologist Professor Margaret Clunies Ross was president from 1995 to 1998, and its current president, cultural studies scholar Professor Lesley Johnson, was elected to the post at the end of 2011. Geographer Professor Fay Gale held the presidency of the ASSA from 1998 to 2000 and was succeeded by economist Professor Sue Richardson for a term from 2001 to 2003. The current, and first female, elected president of the AAS is molecular biologist Professor Suzanne Cory, who assumed the presidency in 2010. All bar one of these women were born in the 1940s. Elected to the academies as outstanding researchers, they had all shown a remarkable range of skills in other academic work including administrative leadership.

\footnotetext{
44 See information on the AAH website: www.humanities.org.au.

45 Professor Tom Healy, Personal communication, Melbourne, 24 April 2012.

46 At the end of 2012, the numbers of female and male fellows of the learned academies stood as follows: the AAH had 561 fellows, including overseas and honorary fellows, of whom 102 were women; the ASSA had 535 fellows, including honorary and overseas fellows, of whom 143 were women; the AAS had more than 400 fellows, of whom 42 were women; and the ATSE had more than 800 fellows, of whom 60 were women. Sources: academy websites. At their elections in 2012, the AAH elected 16 new fellows, eight of whom were women (50 per cent); the ASSA elected 17 new fellows, four of whom were women (approximately 25 per cent); the AAS elected 21 new fellows, four of whom were women (19 per cent); and the ATSE elected 38 new fellows, 11 of whom were women (approximately 29 per cent).
} 
All five held doctorates - Clunies Ross and Cory from Oxford University, but Johnson, Gale and Richardson from Australian universities, indicating that outstanding research training was no longer confined exclusively to top northern-hemisphere universities. By the date of their election to their academies and since, they had carried out outstanding research within lecturing positions. Most had raised children alongside their demanding academic work, which had ceased to be anomalous, though the logistics of combining waged work and child care continued to complicate women's lives rather more than men's. ${ }^{47}$ They were not only internationally known and respected but also had been able, through cheaper travel and through the Internet, to access materials and sustain networks of allied scholars throughout the world, enabling continual collaboration and sharing of knowledge.

All assumed these leadership positions in the academies after undertaking university administrative leadership, several at very senior levels, demonstrating the practice of Australian universities of encouraging their top researchers into administration. Women first entered leadership positions as heads of departments and schools, deans of faculties and heads of research centres, professional associations and national units such as Australian Research Council (ARC) panels. From the appointment in 1987 of Professor Diane Yerbury as Australia's first female vice-chancellor at Macquarie University in Sydney, a small but growing number of women have become deputy vice-chancellors and vice-chancellors.

Margaret Clunies Ross was elected to the AAH in 1990 for outstanding expertise in Old and Middle English language and literature, and Old Norse (Old Icelandic) language and literature. Born in Adelaide in 1942, her first degree was from the University of Adelaide in English and her doctorate was from Oxford University (Somerville College). She served on the council of the AAH before taking up the presidency. She headed a research centre in her area at the University of Sydney. ${ }^{48}$ The second woman appointed as AAH president, Sydney-born Lesley Johnson, was elected to the AAH in 1999 for her scholarly contribution to cultural studies, Australian history and gender studies. Her undergraduate degree was from the University of Sydney; she undertook a Masters of Education at the University of Queensland and a PhD at Monash University. Johnson became pro-vice-chancellor (research) at the University of Technology, Sydney, in 1995, a position she held for nine years; from 2004 to 2009, she was deputy vice-chancellor (research) at Griffith University. Johnson

\footnotetext{
47 See Alexis Coe, 'Being Married Helps Professors Get Ahead, but Only if They're Male', The Atlantic, 17 January 2013.

48 For details on Margaret Clunies Ross, see www.humanities.org.au; University of Sydney website: www. sydney.edu.au; Sharon Maree Harrison, 'Clunies Ross, Margaret Beryl', in The Encyclopedia of Women's Leadership in Twentieth-Century Australia, eds Judith Smart and Shurlee Swain (Australian Women's Archive Project, 2014), http://www.womenaustralia.info/leaders/biogs/WLE0547b.htm.
} 
also served on various ARC committees and for three years was a member of its council. ${ }^{49}$ Professor Anna Haebich and Professor Gillian Whitlock are currently vice-presidents of the AAH - a post several other women have held in the AAH in the past decade: Professors Ros Pesman (2005-06); Anne Freadman (2007); Elizabeth Webby (2007-09); and Kate Burridge (2007-09).

Fay Gale, the second woman to lead an academy and the first to lead the ASSA, was born in Adelaide in 1932, attended the University of Adelaide for her undergraduate and doctoral degrees and was in 1979 elected fellow of the ASSA for her outstanding research that included studies of urban Aborigines. Gale had a distinguished research career, combined with extensive senior administration. In 1978, she became the first woman professor at the University of Adelaide; she was appointed pro-vice-chancellor in 1988 and subsequently became vicechancellor of the University of Western Australia in 1990. She died in 2008. ${ }^{50}$ Sue Richardson, born in Melbourne in 1946, undertook her undergraduate degree at the University of Melbourne and her doctorate at La Trobe University, becoming its first doctoral graduate. Her research has focused on the labour market, and she served for a period as director of the National Institute of Labour Studies at Flinders University of South Australia. ${ }^{51}$ The incoming president of the ASSA in 2013, psychologist Professor Deborah Terry, is another academician who has combined a fine research engagement with senior administration; she is currently Deputy Vice-Chancellor of the University of Queensland.

Suzanne Cory, born in Melbourne in 1942, undertook her first degree at the University of Melbourne and her doctorate at Cambridge University, where she worked in the laboratory of the Nobel Prize winner Francis Crick. ${ }^{52}$ After postdoctoral research, she returned to Melbourne in 1971 to work at the Walter and Eliza Hall Institute of Medical Research in Melbourne. She served as its director from 1996 to 2009. She was elected a fellow of the AAS in 1986 and in

49 For details on Lesley Johnson, see ASSA website: www.assa.edu.au; Sharon Maree Harrison, 'Johnson, Lesley Ruth', in The Encyclopedia of Women's Leadership in Twentieth-Century Australia, eds Judith Smart and Shurlee Swain (Australian Women's Archive Project, 2014), http://www.womenaustralia.info/leaders/biogs/ WLE0552b.htm.

50 For details on Fay Gale, see ASSA website: www.assa.edu.au. See also Fay Gale, 'Taking on the Academy', in Carrying the Banner: Women, Leadership and Activism in Australia, eds Joan Eveline and Lorraine Hayden (Perth: University of Western Australia Press, 1999), 136-44; Sharon Maree Harrison, 'Gale, Gwendoline Fay', in The Encyclopedia of Women's Leadership in Twentieth-Century Australia, eds Judith Smart and Shurlee Swain (Australian Women's Archive Project, 2014), http://www.womenaustralia.info/leaders/biogs/WLE0574b.htm. 51 For details on Sue Richardson, see ASSA website: www.assa.edu.au; Flinders University website: www. flinders.edu.au; Sharon Maree Harrison, 'Richardson, Susan (Sue)', in The Encyclopedia of Women's Leadership in Twentieth-Century Australia, eds Judith Smart and Shurlee Swain (Australian Women's Archive Project, 2014), http://www.womenaustralia.info/leaders/biogs/WLE0570b.htm.

52 For details on Suzanne Cory, see http://science.org.au/fellows/council/index.html; Ragbir Bhathal, 'Suzanne Cory: Medical Scientist', in Profiles: Australian Women Scientists, ed. Ragbir Bhathal (Canberra: National Library of Australia, 1999), 89-98; Sharon Maree Harrison, 'Cory, Suzanne', in The Encyclopedia of Women's Leadership in Twentieth-Century Australia, eds Judith Smart and Shurlee Swain (Australian Women's Archive Project, 2014), http://www.womenaustralia.info/leaders/biogs/WLE054lb.htm. 
1992 became a fellow of the Royal Society of London. She has participated in highly important international as well as national research forums and scholarly organisations. Her work as president of the AAS has included advocacy for girls and women in science.

The ATSE has yet to appoint a woman as president, but Professor Mary O'Kane, a computer engineer in speech recognition, is currently vice-president. Born in 1954 in Mount Morgan, Queensland, her first degree in physics and mathematics was from the University of Queensland and her PhD from The Australian National University. ${ }^{53}$ She was the first female vice-chancellor of the University of Adelaide, chaired the Research Grants Committee of the ARC and is currently the NSW Chief Scientist and Engineer. She serves an academy that is marked, as is the AAS, by a decided gender imbalance. In 2012, 52 of a total of some 800 members were women. ${ }^{54}$ In the AAS in 2012 there were 35 female fellows out of a total of just more than 400, including corresponding fellows. ${ }^{55}$ These figures contrasted fairly strongly with the proportions of fellows in the ASSA and the AAH: 140 women out of 524 fellows (including honorary fellows), in the ASSA; and 94 female fellows out of 524 fellows (including honorary fellows), in the AAH.

The marked gender imbalance in the science academies reflects the gender imbalance in senior science positions in the universities, though there are members of these academies who think they could with effort diminish the size of the gap. The ATSE has taken the somewhat unusual step for a learned academy to redress the gender ratio beginning with the academy's adoption in November 2010 of a gender equity policy. The policy 'recognises leadership is needed to address the gender imbalance both within the Academy membership and its activities as well as more broadly in promoting women in senior level in technological sciences and engineering in Australia'. ${ }^{56}$ In 2011 the academy alerted fellows to an element of bias in their election process when it instituted a positive discrimination policy to increase the numbers of women fellows. It announced the establishment of a target for the election of women, to constitute one-third of new fellows elected each year. ${ }^{57}$

\footnotetext{
53 Ragbir Bhathal, 'Mary O'Kane: Computer Engineer', in Profiles: Australian Women Scientists, ed. Ragbir Bhathal (Canberra: National Library of Australia, 1999), 133-4; Harrison, 'Mary O'Kane'.

54 See information on the ATSE website: www.atse.org.au.

55 See information on the AAS website: www.science.org.au.

56 Australian Academy of Technological Sciences and Engineers (ATSE), 'ATSE Takes Further Gender Equity Steps', Media release, 29 June 2011.

57 Ibid.; Australian Academy of Technological Sciences and Engineers (ATSE). ATSE endorsed the UN Women's Empowerment Principles and the development of a program of action to back ATSE's Gender Equity Policy (including implementing the gender targets for membership) by an ATSE Gender Equity Implementation Group.
} 
We may conclude that women have attained a considerable degree of equity in the tertiary sector in Australia when we look at more than 100 years of participation. We argue that the relative egalitarianism of Australian society has disguised the class and gender biases of access to professional employment: discriminatory access to the upper reaches of secondary education, social conservatism around the family and the strong gender division in workplaces that the countervailing pressure of the women's movement lessened but did not eliminate. This has had considerable implications for women who aspired to or gained work as academics. With the expectation that the state would fund universities, women from the 1920s competed unequally with men for positions in coeducational tertiary institutions. Starting after World War II but with greater frequency from the 1970s, women's increased entry into postgraduate research enabled them a more numerous place in the starting points for tenured positions from which they could be promoted to all levels of the academic hierarchy. Many excelled in research and some assumed academic administrative responsibilities. Fresh challenges to the funding base of universities have once again set in train differing trajectories in academia, given that women's training, entry and ability to sustain a foothold were bound to be comparatively fragile in these circumstances.

Partly because of the uneven spread of women across the disciplines, women in senior administrative positions by the first decade of the twenty-first century were proportionately fewer than men, even at the level of heads of departments, heads of schools and deans of faculties. This gender imbalance was more pronounced at the most senior levels. Universities Australia, the vicechancellors' organisation, has recently discussed ways of identifying women with future career aspirations in senior administration and working to increase female numbers. Perhaps the very structure and assumptions of the positions are what deter women. Some social scientists in the field of leadership and management studies consider women have a distinctive management stylemore consultative and more interested in seeking consensus than men. ${ }^{58}$ Many senior women who participated in a research project in 2005 did not perceive themselves as treated equally as academic leaders, and found the pressure on them to sustain business management practices uncongenial. One female vicechancellor was quoted as saying: 'You have to assert your authority. You're not given authority. You have to take it. Men are given it. It's a very significant difference.' Women were 'still judged more harshly, because they are not seen as legitimate leaders':

When we look at a male manager going into a job we sit there and expect them to be successful and look for success. In Australia things are exactly the opposite for women. There's still a level at which we all 
think at some deep psychological level that the first mistake they make is evidence of the fact that you're waiting for them to fail. I think that the whole issue for women is the amount of time that they've got to get runs on the boards is much less. It's very dangerous for them if there's a major misjudgement of which they're guilty in their reign. ${ }^{59}$

While the research horizons of women rose considerably in the last decades of the twentieth century, analysts of higher education unsettle any tendencies to complacency about the place of women in the new 'enterprise university', querying whether gains women have made would automatically continue. ${ }^{60}$ Successive governments have squeezed the allocation of funds to the tertiary sector, and universities have been compelled to expand the sale of teaching and knowledge to continue their own development. The enrolment of full fee-paying Asian students has gone some way to meet the gap, in addition to the imposition of charges for domestic students to access fee-bearing post-first degree courses. ${ }^{61}$ These changes have put particular pressure on non-professional areas such as the humanities. At a seminar at the University of Melbourne in October 2011, for example, Queensland researchers Glenda Strachan and Robyn May pointed to a trend towards the feminisation of teaching, its increasing casualisation and its consequent devaluation. Women remain most numerous at the first rungs of the academic hierarchy associated with teaching, as casual tutors and demonstrators and temporary lecturers. ${ }^{62}$ Some would deny the claim that women across all levels invest more in teaching than do men, but anecdotally, certainly, women have the reputation of extending more generous attention to individual students and this reduces their involvement in research.

The Workplace Gender Equality Act passed by Julia Gillard's Labor Government in 2012 required all universities to report on five 'gender equality indicators', to identify existing problems and encourage improvements. The long, long trail

59 Chesterman et al., 'Changing the Landscape?' See also: Chesterman et al., '“Not Doable Jobs"'; Chesterman et al., 'The Gendered Impact on Organisations of a Critical Mass of Women in Senior Management'.

60 See Joan Eveline, Ivory Basement Leadership: Power and Invisibility in the Changing University (Perth: University of Western Australia Press, 2004); Ann Brooks and Alison Mackinnon, eds, Gender and the Restructured University: Changing Management and Culture in Higher Education (Buckingham, UK: Society for Research into Higher Education and Open University Press, 2001); A. Toy Caldwell-Colbert and Judith E. N. Albino, 'Women as Academic Leaders: Living the Experience from Two Perspectives', in Women and Leadership: Transforming Visions and Diverse Voices, eds Jean Lau Chin, Bernice Lott, Joy K. Rice and Janis Sanchez-Hucles (Maldon, Mass.: Blackwell, 2007).

61 Emmaline Bexley, Richard James and Sophie Arkoudis, The Australian Academic Profession in Transition: Addressing the Challenge of Reconceptualising Academic Work and Regenerating the Academic Workforce (Melbourne: Centre for the Study of Higher Education, University of Melbourne, 2011); Simon Marginson and Mark Considine, The Enterprise University: Power, Governance and Reinvention in Australia (Melbourne: Cambridge University Press, 2000); Andrew Norton, Mapping Australian Higher Education (Melbourne: Grattan Institute, 2012); Tony Coady, ed., Why Universities Matter: A Conversation about Values, Means and Directions (Sydney: Allen \& Unwin, 2000).

62 Glenda Strachan and Robyn May, 'The Feminisation of the Academy? Statistics, Structures and Stories', Paper presented at the Symposium on Workplace Culture in Higher Education, University of Melbourne, October 2011. 
of women in the academic profession in Australia still has a way to go before women attain, if not as the old song ran, the 'land of their dreams', then at least a position of relative equity. In the area of research, we can say numbers of scholars have persisted in cutting-edge research to the point where they have become leaders in their fields and influenced significantly the research endeavours of rising generations in this country and internationally.

\section{References}

Academy of Social Sciences in Australia. 'Emeritus Professor Jacqueline Goodnow.' Academy Fellows. http://www.assa.edu.au/fellowship/fellow/116.

Allen, Nessy. 'Australian Women in Science: Two Unorthodox Careers.' Women's Studies InternationalForum 15(5-6) (1992): 551-62.

Allen, Nessy. 'Helen Newton Turner and the Wool Industry.' Journal of Australian Studies 33 (1992): 56-62.

Anderson, Jaynie. 'Ursula Hoff (1909-2005).' http://www.humanities.org.au/ Fellowship/Obituaries.aspx.

'ANU Presentation to the Review of the Institute of Advanced Studies 1990.' Typescript.

Australian Academy of Technological Sciences and Engineers (ATSE). Website. www.atse.org.au/.

Australian Academy of Technological Sciences and Engineers (ATSE). 'Women Prominent among New ATSE Fellows.' Media release, 3 November 2011.

Bexley, Emmaline, Richard James and Sophie Arkoudis. The Australian Academic Profession in Transition: Addressing the Challenge of Reconceptualising Academic Work and Regenerating the Academic Workforce. Melbourne: Centre for the Study of Higher Education, University of Melbourne, 2011.

Bhathal, Ragbir. 'Mary O'Kane: Computer Engineer.' In Profiles: Australian Women Scientists, edited by Ragbir Bhathal, 133-4. Canberra: National Library of Australia, 1999.

Bhathal, Ragbir. 'Mollie Holman: Physiologist.' In Profiles: Australian Women Scientists, edited by Ragbir Bhathal, 99-106. Canberra: National Library of Australia, 1999.

Bhathal, Ragbir, ed. Profiles: Australian Women Scientists. Canberra: National Library of Australia, 1999. 
Bhathal, Ragbir. 'Suzanne Cory: Medical Scientist.' In Profiles: Australian Women Scientists, edited by Ragbir Bhathal, 89-98. Canberra: National Library of Australia, 1999.

Blainey, Ann. 'Bassett, Lady Flora Marjorie (Marnie) (1889-1980).' Australian Dictionary of BiographyOnline. Canberra: National Centre of Biography, The Australian National University. http://adb.anu.edu.au/biography/bassettlady-flora-marjorie-marnie-9448/text16613.

Boreham, Paul, Alec Pemberton and Paul Wilson, eds. The Professions in Australia: A Critical Appraisal. Brisbane: University of Queensland Press, 1976.

Borrie, Wilfred David. 'Dr Jean Isobel Martin.' In Annual Report of the ASSA 1978-1979.

Bourdieu, Pierre. Homo Academicus. Paris: Editions de Minuit, 1984.

Brady, Veronica. South of My Days: A Biography of Judith Wright. Sydney: Angus \& Robertson, 1998.

Brooks, Ann and Alison Mackinnon, eds. Gender and the Restructured University: Changing Management and Culture in Higher Education. Buckingham, UK: Society for Research into Higher Education and Open University Press, 2001.

Campbell, K. S. W. and J. S. Jell. 'Dorothy Hill 1907-1997.' Historical Records of Australian Science 12(2) (1998): 205-28.

Carey, Jane. 'Departing from their Sphere? Australian Women and Science, 1880-1960.' PhD thesis, University of Melbourne, 2003.

Carey, Jane and Patricia Grimshaw. Women Historians and Women's History: Kathleen Fitzpatrick (1905-1990), Margaret Kiddle (1914-1958) and the Melbourne History School. Melbourne: Department of History, University of Melbourne, 2001.

Cass, Bettina. Why So Few? Women Academics in Australian Universities. Sydney: University of Sydney Press, 1983.

Chesterman, Colleen, Anne Ross-Smith and Margaret Peters. 'Changing the Landscape? Women in Academic Leadership in Australia.' http://65.54.113.26/Publication/6223987/changing-the-landscape-womenin-academic-leadership-in-australia.

Chesterman, Colleen, Anne Ross-Smith and Margaret Peters. "'Not Doable Jobs": Exploring Women's Attitudes to Academic Leadership Roles.' Women's Studies International Forum 28(2) (2005): 163-80. 
Chesterman, Colleen, Anne Ross-Smith and Margaret Peters. 'The Gendered Impact on Organisations of a Critical Mass of Women in Senior Management.' Policy and Society 24(4) (2005): 69-91.

Coady, Tony, ed. Why Universities Matter: A Conversation about Values, Means and Directions. Sydney: Allen \& Unwin, 2000.

Coe, Alexis. 'Being Married Helps Professors Get Ahead, but Only if They're Male.' The Atlantic, 17 January 2013.

Connell, Raewyn. 'Core Activity: Reflexive Intellectual Workers and Cultural Crisis.' Journal of Sociology 42(1) (2006): 5-23.

Connell, Raewyn and June Crawford. 'Mapping the Intellectual Labour Process.' Journal of Sociology 43(2) (2007): 187-205.

Crawford, Patricia and Myrna Tonkinson. The Missing Chapters: Women Staff at the University of Western Australia, 1963-1987. Perth: Centre for Western Australian History, University of Western Australia, 1988.

Davison, Graeme. 'Phoenix Rising: The Academy and the Humanities in 1969.' Humanities Australia 1 (2010): 6-14.

Davison, Graeme and Kate Murphy. University Unlimited: The Monash Story. Sydney: Allen \& Unwin, 2012.

Dawson, Madge and Heather Radi, eds. Against the Odds: Fifteen Professional Women Reflect on their Lives and Careers. Sydney: Hale \& Iremonger, 1984.

'Dr John Cole, Interview with Dorothy Hill.' 1981. www.sciencearchive.org.au/ fellows/memoirs/hill.html.

Eveline, Joan. Ivory Basement Leadership: Power and Invisibility in the Changing University. Perth: University of Western Australia Press, 2004.

Fenner, Frank. The Australian Academy of Science: The First Twenty-Five Years. Canberra: Australian Academy of Science, 1980.

Fitzgerald, Tanya, Julie White and Helen M. Gunter, eds. Hard Labour? Academic Work and the Changing Landscape of Higher Education. Bingley, UK: Emerald Electronic Resource, 2012.

Fitzpatrick, Kathleen Collection. University of Melbourne Archives, Melbourne. Fitzpatrick, Kathleen. Martin Boyd. Melbourne: Lansdowne Press, 1963. 
Fitzpatrick, Kathleen. 'A Cloistered Life.' In The Half-Open Door: Sixteen Modern Australian Women Look at Professional Life and Achievement, edited by Patricia Grimshaw and Lynne Strahan, 118-33. Sydney: Hale \& Iremonger, 1982.

Fitzpatrick, Kathleen. Solid Bluestone Foundations and Other Memories of a Melbourne Girlhood 1908-1928. Melbourne: Macmillan, 1983.

Fowler, Kenneth F. 'Neumann, Hanna (1914-1971).' In Australian Dictionary of Biography. Volume 15. Melbourne: Melbourne University Press, 2000.

Gale, Fay. 'Taking on the Academy.' In Carrying the Banner: Women, Leadership and Activism in Australia, edited by Joan Eveline and Lorraine Hayden, 136-44. Perth: University of Western Australia Press, 1999.

Goodnow, Jacqueline. Interviewed by Nikki Henningham, 2005, National Library of Australia Oral History and Folklore Collection, ORAL TRC 5547. National Library of Australia, Canberra.

Grimshaw, Patricia and Jane Carey. 'Foremothers VI: Kathleen Fitzpatrick (19051990), Margaret Kiddle (1914-1958) and Australian History after the Second World War.' Gender \& History 13(2) (August 2001): 349-73.

Grimshaw, Patricia and Rosemary Francis. 'Women Research Leaders in the Australian Learned Academies: 1954-1976.' In Seizing the Initiative: Australian Women Leaders in Politics, Workplaces and Communities, edited by Rosemary Francis, Patricia Grimshaw and Ann Standish, 223-46. Melbourne: eScholarship Research Centre, University of Melbourne, 2012.

Grimshaw, Patricia and Lynne Strachan, eds. The Half-Open Door: Sixteen Modern Australian Women Look at Professional Life and Achievement. Sydney: Hale \& Iremonger, 1982.

Grimshaw, Patricia, John Murphy and Belinda Probert, eds. Double Shift: Working Mothers and Social Change in Australia. Melbourne: Circa, 2005.

Grimshaw, Patricia, Nell Musgrove and Shurlee Swain. 'The Australian Labour Movement and Working Mothers in the United Nation's Decade for Women, 1975-1985.' In The Time of their Lives: The Eight Hour Day and Working Life, edited by J. Kimber and P. Love, 137-52. Melbourne: Australian Society for the Study of Labour History, 2007.

Groves, Matthew, ed. Law and Government in Australia: Essays in Honour of Enid Campbell. Melbourne: Federation Press, 2005.

Groves, Matthew. 'Obituary: Enid Mona Campbell AC, OBE, 1932-2010.' AIAL Forum 63 (2009): 1-3. 
Harrison, Sharon Maree. 'Clunies Ross, Margaret Beryl.' In The Encyclopedia of Women's Leadership in Twentieth-Century Australia, edited by Judith Smart and Shurlee Swain. Australian Women's Archive Project, 2014. http://www. womenaustralia.info/leaders/biogs/WLE0547b.htm.

Harrison, Sharon Maree. 'Cory, Suzanne.' In The Encyclopedia of Women's Leadership in Twentieth-Century Australia, edited by Judith Smart and Shurlee Swain. Australian Women's Archive Project, 2014. http://www. womenaustralia.info/leaders/biogs/WLE054lb.htm.

Harrison, Sharon Maree. 'Gale, Gwendoline Fay.' In The Encyclopedia of Women's Leadership in Twentieth-Century Australia, edited by Judith Smart and Shurlee Swain. Australian Women's Archive Project, 2014. http://www. womenaustralia.info/leaders/biogs/WLE0574b.htm.

Harrison, Sharon Maree. 'Johnson, Lesley Ruth.' In The Encyclopedia of Women's Leadership in Twentieth-Century Australia, edited by Judith Smart and Shurlee Swain. Australian Women's Archive Project, 2014. http://www. womenaustralia.info/leaders/biogs/WLE0552b.htm.

Harrison, Sharon Maree. 'O'Kane, Mary Josephine.' In The Encyclopedia of Women's Leadership in Twentieth-Century Australia, edited by Judith Smart and Shurlee Swain. Australian Women's Archive Project, 2014. http://www. womenaustralia.info/leaders/biogs/WLE0666b.htm.

Harrison, Sharon Maree. 'Richardson, Susan (Sue).' In The Encyclopedia of Women's Leadership in Twentieth-Century Australia, edited by Judith Smart and Shurlee Swain. Australian Women's Archive Project, 2014. http://www. womenaustralia.info/leaders/biogs/WLE0570b.htm.

Holden, Colin. The Outsider: A Portrait of Ursula Hoff. Melbourne: Australian Scholarly Publishing, 2009.

Holman, Mollie. Interviewed by Ragbir Bhathal, 1997, National Library of Australia Oral History and Folklore Collection, ORAL TRC 3600. National Library of Australia, Canberra.

Hooker, Claire. Irresistible Forces: Australian Women in Science. Melbourne: Melbourne University Press, 2004.

Horne, Julia and Geoff Sherington. Sydney: The Making of a Public University. Melbourne: Melbourne University Publishing, 2012.

'Interview by Professor Bob Crompton with Bernard Neumann.' 1998. www. sciencearchive.org.au/scientists/interviews/n/bn.html. 
'Jacqueline Jarrett Goodnow.' In Women in Psychology: A Biobibliographic Sourcebook, edited by A. N. O'Connell and M. K. Russo, 134-42. New York: Greenwood Press, 1990.

Kelly, Farley. Degrees of Liberation: A Short History of Women in the University of Melbourne. Melbourne: Women Graduates Centenary Committee, University of Melbourne, 1985.

Kelly, Farley. On the Edge of Discovery: Australian Women in Science. Melbourne: Text Publishing, 1993.

Kingston, Beverley. My Wife, My Daughter, and Poor Mary Ann: Women and Work in Australia. Melbourne: Thomas Nelson, 1975.

'Kramer, Leonie Judith.' In The Oxford Companion to Australian History, edited by Graeme Davison, John Hirst and Stuart Macintyre. Melbourne: Oxford University Press, 2000.

'Kramer, Leonie Judith, (1924-).' http://www.womenaustralia.info/biogs/ IMP0037b.htm.

Lake, Marilyn. Getting Equal: The History of Australian Feminism. Sydney: Allen \& Unwin, 1999.

Lamont, Michele. How Professors Think: Inside the Curious World of Academic Judgment. Cambridge, Mass.: Harvard University Press, 2009.

Lawler, James. 'Robinson-Valery, Judith Ogilvie (1933-2010).' www.humanities. org.au/Fellowship/Obituaries.aspx.

'McArthur, Norma (1921-1984).' Obituaries AustraliaOnline. Canberra: National Centre of Biography, The Australian National University. http://oa.anu.edu. au/obituary/mcarthur-norma-677/text678.

McCalman, Janet. Journeyings: The Biography of a Middle-Class Generation 1920-1990. Melbourne: Melbourne University Press, 1995.

McCarthy, Gavan. 'Turner, Helen Alma Newton (1908-1995).' In Encyclopedia of Australian Science. www.eoas.info/biogs/P004129b.

Macintyre, Stuart and Richard Selleck. A Short History of the University of Melbourne. Melbourne: Melbourne University Press, 2003.

Macintyre, Stuart. The Poor Relation: A History of the Social Sciences in Australia. Melbourne: Melbourne University Press, 2010.

Macintyre, Stuart and Peter McPhee, eds. Max Crawford's School of History. Melbourne: History Department, University of Melbourne, 2000. 
Diversity in Leadership: Australian women, past and present

Mackinnon, Alison. The New Women: Adelaide's Early Women Graduates. Adelaide: Wakefield Press, 1986.

Mackinnon, Alison. Love and Freedom: Professional Women and the Reshaping of Personal Life. Melbourne: Cambridge University Press, 1997.

Mackinnon, Alison. Women, Love and Learning: The Double Bind. New York: P. Lang, 2012.

Marginson, Simon and Mark Considine. The Enterprise University: Power, Governance and Reinvention in Australia. Melbourne: Cambridge University Press, 2000.

Moyal, Ann, ed. Portraits in Science. Canberra: National Library of Australia, 1994.

Newman, Michael and Gordon Wall. 'Hanna Neumann 1914-1971.' Records of the Australian Academy of Science 3(2) (1975). http://sciencearchive.org.au/ fellows/memoirs/neumann.html.

Norton, Andrew. Mapping Australian Higher Education. Melbourne: Grattan Institute, 2012.

Patrick, Alison. 'Fitzpatrick, Kathleen Elizabeth (1905-1990).' Australian Dictionary of BiographyOnline. Canberra: National Centre of Biography, The Australian National University. http://adb.anu.edu.au/biography/ fitzpatrick/kathleen-elizabeth-12500/text22491.

Pickering, Robert. 'Judith Robinson-Valery, 1933-2012.' Australian Journal of French Studies (September 2010).

Poynter, John and Carolyn Rasmussen. A History of the University of Melbourne, 1935-1975. Melbourne: J. R. Poynter, 1995.

Richmond, Katy. 'Martin, Jean Isobel (1923-1979).' Australian Dictionary of Biography. Volume 15. Melbourne: Melbourne University Press, 2000.

Sherratt, Tim. 'Finding Life in Ancient Corals: Dorothy Hill.' Australasian Science (Summer 1995). Australian Science Archives Project. http://www. asap.unimelb.edu.au/bsparcs/exhib/journal/as_hill.htm.

Sinclair, Amanda. Doing Leadership Differently: Gender, Power, and Sexuality in a Changing Business Culture. Melbourne: Melbourne University Press, 1998.

Sinclair, Amanda. Leadership for the Disillusioned: Moving beyond Myths and Heroes to Leading that Liberates. Sydney: Allen \& Unwin, 2007. 
Sinclair, Amanda. 'Not Just “Adding Women In": Women Re-Making Leadership.' In Seizing the Initiative: Australian Women Leaders in Politics, Workplaces and Communities, edited by Rosemary Francis, Patricia Grimshaw and Ann Standish, 15-36. Melbourne: eScholarship Research Centre, University of Melbourne, 2012.

Strachan, Glenda and Robyn May. 'The Feminisation of the Academy? Statistics, Structures and Stories.' Paper presented at the Symposium on Workplace Culture in Higher Education, University of Melbourne, October 2011.

Thornton, Margaret. 'The Mirage of Merit: Constructing the "Ideal Academic".' Paper presented at the Symposium on Workplace Culture in Higher Education, University of Melbourne, October 2011.

Toy Caldwell-Colbert, A. and Judith E. N. Albino. 'Women as Academic Leaders: Living the Experience from Two Perspectives.' In Women and Leadership: Transforming Visions and Diverse Voices, edited by Jean Lau Chin, Bernice Lott, Joy K. Rice and Janis Sanchez-Hucles. Maldon, Mass.: Blackwell, 2007.

Turner, Helen Newton. Interviewed by Ann Moyal, 1993, National Library of Australia Oral History and Folklore Collection, ORAL TRC 2902. National Library of Australia, Canberra.

Walker, Rosanne. 'Hanna Neumann (1914-1971).' Australasian Science 22(1) (2001).

Wall, G. E. 'Hanna Neumann.' Journal of the Australian Mathematical Society 17(1) (1974): 1-28.

Ward, Beverley. 'The Female Professor: A Rare Australian Species, the Who and How.' PhD thesis, Murdoch University, Perth, 2003.

Webby, Elizabeth. 'Judith Wright McKinney (1915-2000) Obituary.' http:// www.humanities.org.au/Fellowship/Obituaries.asp.

Wetherell, David. 'Wedgwood, Camilla Hildegarde (1901-1955).' Australian Dictionary of Biography Online. Canberra: National Centre of Biography, The Australian National University. http://adb.anu.edu.au/biography/ wedgwood-camilla-hildegarde-1 1992/text21503.

Witz, Anne. Professions and Patriarchy. London and New York: Routledge, 1992.

Wright, Judith. Half a Lifetime, edited by Patricia Clarke. Melbourne: Text Publishing, 1999. 


\section{Diversity in Leadership: Australian women, past and present}

Zillman, John W. ATSE 1975-2005: The First 30 Years - A Short History of the Origins and Development of the Australian Academy of Technological Sciences and Engineering (ATSE). Melbourne: ATSE, 2005. 
This text taken from Diversity in Leadership: Australian women, past and present, edited by Joy Damousi, Kim Rubenstein and Mary Tomsic, published 2014 by ANU Press, The Australian National University, Canberra, Australia. 